\title{
Principal Leadership In an Effort to Improve Student Entrepreneurship Competence
}

\author{
Engkus Kuswarno' ${ }^{1)}$, Ibrahim Danuwikarsa ${ }^{2)}$, \\ Faiz Karim Fatkhullah $^{3)}$, Roli Fola Cahya Hartawan ${ }^{4) *}$ \\ ${ }^{1)}$ Chancellor of Universitas Islam Nusantara Bandung \\ ${ }^{2)}$ Faculty of Agriculture, Agrotechnology Study Program, UNINUS Bandung \\ ${ }^{3)}$ FKIP, Early Childhood Education Teacher Education Study Program, UNINUS Bandung \\ 4) Indonesian Language and Literature Education, STKIP PGRI Metro Lampung \\ *Coresponding Author \\ Email :rolifola@gmail.com
}

\begin{abstract}
This research is motivated by the low entrepreneurial competence of vocational students, so that it has an impact on the lack of vocational graduates who open new jobs. The approach in this study is descriptive qualitative, so the purpose of this study is to describe and analyze 1) the leadership characteristics of the principals of SMKN 1 and SMKN 4 Metro Lampung, 2) the principal's leadership strategy which includes the application of environmental analysis., strategy formulation, strategy implementation and strategy evaluation, 3) Excellent entrepreneurship program. SMKN, 4) the obstacles faced, and 5) solutions to overcome these problems. The results of the study: 1) The principal of SMKN implements transformational leadership 2) The principal has implemented a strategy to improve the quality of graduates but has not yet been formulated in the school's RKS/RKAS. 3) The implementation of entrepreneurship programs in SMKN has been integrated with very high and entrenched education and entrepreneurial values in schools. 4) There are several obstacles for the principal in an effort to improve the entrepreneurial competence of students. 5) There is a solution to overcome the obstacles for the Principal in an effort to improve the entrepreneurial competence of students.
\end{abstract}

Keywords: Leadership, Transformational, leadership strategy

\section{INTRODUCTION}

Today education is faced with the challenge of increasing the quantity and quality of vocational education in an effort to meet local and national needs and be able to compete globally. To achieve this, all Vocational High Schools are given regulations to provide entrepreneurial development coaching services. In line with the National Education Ministry's Plan, in the Smk Development Road Map 2010-2014 on the Vision of the Directorate of Vocational Development, it is expected to realize Vocational High School that can produce entrepreneurial graduates who are ready to work, smart, competitive, and have the identity of the nation, and able to develop local advantages and can compete in the global market.

Vocational high school is one form of formal education unit that organizes vocational education at the secondary education level as an extension of Junior High School, or other equivalent or advanced form of learning outcomes that are recognized equally or equally. In a Journal of Economic Education entitled Implementation of Entrepreneurship Competence of Principals in Organizing Bussiness Centre "SMK Mart" explained that vocational high schools as one of the models of educational institutions basically have several objectives, namely: 1) preparing students to enter the field and develop a professional attitude; 2) preparing students to be able to choose a career, able to compete and able to develop themselves; 3 ) prepare a mid-level workforce to fill the needs of the business and industrial world at this time and in the future, and 4) prepare graduates to become productive, adaptive and creative citizens. Therefore, vocational high school actually have a very relevant responsibility towards the 
formation of the entrepreneurial spirit of its graduates. The contribution of vocational high school in this issue continues to be questioned by various parties. Because on the other hand vocational high school graduates who can directly enter the workforce after graduation are still far from expectations.

The inequality between high labor growth and low employment growth has impacted the increasingly low employment rate of Vocational High School graduates . In order for the absorption of graduates to be high, one of the government efforts that need to be done is to make a policy of regulation for the establishment of Vocational High Schools that can be adjusted to the business field sector and employment profile at the local, national, and international levels that will be very useful to plan needs in the future. Indirectly, this is a way for Vocational High Schools to provide labor in accordance with the needs of the business world and industries relevant to the resources of each region. The needs of the education program are determined by the need for job qualifications and workforce skills that are needed to develop various sectors based on existing reality, entrepreneurial education in Indonesia is still not getting adequate attention, both by the world of education and the community. Many educators pay less attention to the growth of character and entrepreneurial behavior of learners, both in vocational schools, and in professional education. Their orientation, in general, is only on preparing the workforce. For that, it is necessary to find a solution, how education can play a role to turn humans into humans who have entrepreneurial character and or behavior..

Apart from various shortcomings in educational practice in Indonesia, when viewed from the national standard of education that is a reference for curriculum development, entrepreneurial education is also included in the material that must be taught and mastered and realized by learners in everyday life. The problem is, entrepreneurial education in schools has only touched on the level of introduction of norms or values, and not yet at the level of internalization and concrete action in everyday life.

Based on these problems, it takes a good principal leadership strategy to increase student entrepreneurship in Vocational High Schools. As based on previous research that "The principal's leadership strategy is a way to overcome all obstacles or challenges by utilizing all school resources, including improving the professionalism of teachers to achieve school goals" (Fakhrunnisa, 2019). "The principal's leadership strategy is the activity of making decisions or designing strategic actions to achieve the organization's goals set so that it can be achieved effectively and efficiently" (Yulmawati, 2016).

Implementation of the principal's strategy in research conducted by Suriansyah \& Aslamiah (2015) found that "the strategies applied by principals in shaping student character include philosophical communication, vision, mission clearly, transparency, discipline, instructional leadership, quality leadership, and teacher empowerment and education personnel" . While in research conducted by Sriwahyuni, Kristiawan, and Wachidi (2019) found "the strategy of the principal of State Vocational High School 2 Bukittinggi in implementing national standards of education is different in accordance with their respective standards. In implementing the content standards formed the curriculum development team collaborates with the business world in conducting curriculum development. In implementing the standard process of learning based on Information and Technology. In implementing the standard of competence of graduates by improving academic achievement through the Student Skills Competition, increasing the number of graduates ready for work by honing the entrepreneurial spirit and activities of the FieldWork Program. In implementing the standards of educators and education personnel by improving the competence of educators and education personnel through training, and the like. In implementing facilities and infrastructure standards with planning, procurement, maintenance and inventory of school facilities and infrastructure. In implementing management standards by preparing a School Budget Activity Plan, 
formulating and socializing the vision and mission of the school and implementing ISO 90012008 quality management. In implementing financing standards by making planning, managing and reporting school financing. In implementing assessment standards by conducting information and technology-based assessments. The problem that is usually encountered in the implementation of the principal's leadership strategy is related to financing."

Based on preliminary studies conducted at SMKN 1 and SMKN 4 Metro Lampung, various problems are indicated that reflect the low entrepreneurial competence of graduates, where the results of entrepreneurship graduates within more than 12 months after graduation are less than 50\%. Thus it is necessary to strive to improve the entrepreneurial competence of students through the optimization of the principal's leadership. As Kirzer's theory highlights about human performance, its tenacity, seriousness, earnestness for self-sufficiency, in trying, so that the back and forth of a business depends on the effort and tenacity of the entrepreneur. Kirzer used Misesian's view of "Human Kirzer", in analyzing entrepreneurial. According to Kirzer, by utilizing superior knowledge, an entrepreneur can make a profit, Kirzer also said, "This insight is simply that for any entrepreneurial discovery creativity is never enough: it is necessary to recognize one" own creativity. (Sutrisna Dewi; 2017:41; Sutisna :2020).

Leadership is the process of effectively influencing or mobilizing others effectively and efficiently to achieve organizational goals. This is as Sanusi (2009:19); "Leadership has the following impact First, leadership means involving others or other parties, namely employees or subordinates. Employees or subordinates must have the willingness to receive direction from the leader. Second, an effective leader is someone who with his power is able to arouse his followers to achieve satisfactory performance. Third, leadership must have honesty with oneself, a sincere attitude of responsibility, knowledge, courage to act in accordance with the keyakinan, confidence in yourself and others and the ability to convince others in building the organization"

Leadership is the ability to take initiative in social situations to create new forms and procedures, design and organize actions and in doing so to generate cooperation towards achieving goals. (Danim; 2012:6). Further explained by Sudarwan Danim; "Leadership is any action taken by an individual or group to coordinate and give direction to another individual or group belonging to a particular container to achieve previously established goals". Leadership is the ability to coordinate, direct, move and influence others toward achieving goals effectively and efficiently. But to achieve these goals requires the right leadership style and strategy.

One of the right leadership styles to enhance students' entrepreneurial competencies is transformational leadership styles. As Bernard Bass (Stone et al, 2004) in Sudarwan Danim (2009:50) says as follows: "Transformational leaders transform the personal values of followers to support the vision and goals of the organization by fostering an environment where relationships can be formed and by establishing a climate of trust in which visions can be shared". Furthermore, operationally Bernard Bass (Gill et al, 2010) in Sudarwan Danim (2009: 52) interprets transformational leadership as follows: "Leadership and performance beyond expectations". Agreeing with this theory, Sudarwan Danim (2009: 59) explains that "Transformational comes from the word "to transform" which means transforming or transforming something into a different form. The essence of transformatip leadership is to turn potential into real energy, turning the potential of institutions into energy to improve the quality of learning processes and outcomes." So, the leadership of the principal can be defined as a form (style) applied in influencing subordinates consisting of teachers, administrative personnel, students, and parents of learners. A leader is said to be transformational if he can change the situation, change what is commonly done, talk about lofty goals, have references to 
the values of freedom, justice and equality. Transformational leaders will make subordinates see that the goals they want to achieve are more than just their personal interests.

Related to strategy, J L Thompson, defines strategy as a way to achieve an end result. The end result concerns the goals and objectives of the organization. There are broad strategies for the entire organization and competitive strategies for each activity. Meanwhile, functional strategies directly encourage copetitive strategies. Bennet, describes strategy as the chosen direction orgnization to follow in achieving its mission". (Yulmawati, 2016:18) .

In strategy preparation leaders need expertise to formulate a good strategy, so it takes a strategy management as in the science of strategy management according to Thomas $\mathrm{L}$ Wheelen \&J. David Hunger (2008), defining that strategic management is a series of managerial decisions and actions that determine the long-term performance of the company. It includes scanning the environment (both external and internal) to look at weaknesses and advantages as well as opportunities and threats to the company, strategy formulation (strategy or long-term planning) as well as the implementation and evaluation of strategy control.

1. Environmental Analysis

David Hunger (2003) divides environmental analysis activities into internal and external environmental analaisis. Swot analysis has become a common tool used in education strategy planning, which in its management will be associated with inputs, processes and outputs. SWOT can be divided into two elements: internal analysis (test of strengths and weaknesses) and external or environmental analysis (opportunities and threats). The purpose of this test is to maximize strength, create minimal weaknesses, reduce threats, and build opportunities.

2. Strategy formulation

Strategy formulation is the development of a long-term plan for the effective management of opportunities and threats, judging by the strengths and weaknesses of the company. Strategy formulation includes determining the company's mission, determining achievable goals, strategy development, and setting policy guidelines. (Hunger and Wheelen, 2003).

3. Implementation of strategy

Hunger (2003) says that "Strategi implementation is the process by which management realizes its policy strategy in action through the development of programs, budgets and procedures."

4. Evaluation and control strategies

Hunger (2003) defines that "Strategy evaluation is the stage of the assessment process of a company's actual performance results compared to expected performance. Managers at all levels use performance outcome information to take remedial action and troubleshoot problems.

Thus, it can be concluded that if you want to determine the strategy in an organization, leaders should know in advance what are the advantages and weaknesses of the competitors and pay attention to other factors so that in carrying out the strategy later can be superior to other competitors. In addition, the leader should also implement the strategy he formulated and evaluate the strategy that has been implemented. As the purpose of this research is to describe and analyze leadership styles, leadership strategies, superior programs of entrepreneurship in SMKN 1 and SMKN 4 Metro Lampung and its constraints and solutions. 


\section{RESEARCH METHODS}

This research uses a qualitative approach with Case Study research methods, aiming to understand the subject in depth and thoroughly. The reason for the selection of this approach is that the author wants to dig deeper into the various processes that run naturally, so that the author can describe according to the phenomena that occur at the research site. As Yin (2013) "Case Studies presents strategies that are more suitable for research yang the subject of research questions that are familiar with how or why".

The research techniques used in this study are interviews, observations, and documentation. The following will be explained from each data collection technique, namely:

1. In-Depth Interview/Indepth Interview

In the framework of data collection, researchers conducted structured or unstructured interviews to get information or orally established statements from an informant who was directly involved in organizing the leadership of the principal in an effort to improve the entrepreneurial competence of students in SMKN 1 and SMKN 4 Metro Lampung, namely the Principal, Deputy Principal, Education Personnel, Program Head and students. The aspects interviewed were related to leadership styles, leadership strategies, entrepreneurial innovation programs, the obstacles facing schools and solutions to overcome them.

2. Documentation Studies

The documents collected are documents that contain data on student entrepreneurship in SMKN 1 and SMKN 4 Metro Lampung namely Strategy Plan, Work Plan and School Budget, MoU of Partnership with The Business and Industry World, FieldWork Practice Procedures, Semester Learning Plan and Syllabus.

3. Field Observation

Observations are carried out by looking, interviewing, systematically recording the elements, symptoms and actual practice in the subjects studied to find out the actual conditions, namely the Principal, Deputy Principal, Education Personnel, Head of Program and Students. Aspects observed are the headmaster's leadership style, principal leadership strategy, entrepreneurial innovation program at SMKN 1 and SMKN 4 Metro Lampung, the obstacles facing the school and the principal's solution to overcome it.

The main instrument of data collection in a qualitative study is the researcher himself, as Sugiyono (2012:102) states, that "a research instrument is a tool used to measure specificly observed natural and social phenomena, all of these phenomena are pinched by research variables". The research subjects are the source of data requested in accordance with their knowledge and involvement in the case of low student entrepreneurial competence. The source of data in qualitative research of case study methods according to Nawawi (2003: 2) is "The source of data can be obtained not only from the case studied, but also can be obtained from all parties who know and know the case well. In other words, data in case studies can be obtained from a variety of sources but is limited in the cases to be studied." Based on these opinions, research subjects that are considered to meet the characteristics are the Principal, Wakasek Curriculum, educators, education personnel, Head of Expertise Program, and students. The data analysis technique is carried out as follows:

1. Data reduction/ data reduction, namely the process of selection, alignment, abstracting or transparency of data obtained in the field either through observation or interview to the base informant and key informant. Data reduction is a form of sharpening, classifying, directing, discarding unnecessary data, and organizing data so that conclusions can be drawn and fermented. 
2. Presentation of data / Data Display, which is a set of information and data that gives the possibility of drawing conclusions and taking action. The presentation can be in the form of descriptions, graphs, and charts.

3. Conclusion withdrawal, which is the final analysis obtained based on the results of data reduction and data presentation.

Thus, the data analysis technique used is clear, namely, directed to answer the formulation of research problems, namely analyzing data related to the Principal's leadership style, Principal leadership strategy, entrepreneurial innovation program, obstacles experienced by schools and how to overcome them.

\section{RESULTS AND DISCUSSION}

The nature of principal leadership in improving the competence of entrepreneurship students in SMK $n 1$ and $\mathbf{N} 4$ Metro Lampung

The principals of SMKN 1 and SMKN 4 Metro Lampung are transformasional style leaders with a high entrepreneurial ethos. The principal is able to empower and mobilize all resources at their disposal to achieve the school's goal of improving the entrepreneurial competence of graduates.

The strategy of principal leadership in improving the competence of entrepreneurship students in SMK n 1 and $\mathbf{N}$ Metro Lampung

The Principal has made environmental observations from two aspects both internally and externally so that the output produced can be absorbed in the world of work. As a result of environmental observations there are many program innovations along with the development of the needs of the world of work, so that schools get various awards and achievements. The Principal has formulated / formulated a strategy but not optimal, this is because the school only formulates the vision, mission and goals of the school, and sets policy guidelines for achieving graduate competence, but the development of strategies to achieve these goals has not been poured into the School Work Plan. Kepala Sekolah has carried out program development that is integrated with education and entrepreneurial values, compiling and using the budget according to the needs of the program and establishing its implementation procedures. The Principal has carried out a comprehensive evaluation and control strategy. Evaluation is carried out on the teaching program and on the process of teaching implementation.

\section{Entrepreneurship programs in efforts to improve the competence of entrepreneurship students in SMK n 1 and $\mathbf{N} 4$ Metro Lampung}

The implementation of entrepreneurship programs at State Vocational High School has been integrated with very high education and entrepreneurial values and culture in schools. Hopefully, students have the value of confidence, creativity, independence, a sense of responsibility, innovative, to be able to find ideas of business and entrepreneurship opportunities. In its implementation, these values have indeed been prepared and embedded in a Learning Implementation Plan and syllabus. Just like in basic competencies there is the value of entrepreneurship that is future-oriented and dare to take risks.

The obstacles encountered in the leadership of the head of the school in an effort to improve the competence of entrepreneurship students in SMK $n 1$ and N 4 Metro Lampung

There are several obstacles for the Principal in an effort to improve the entrepreneurial competence of students including: 
a. Currently traditional learning methods and learning media that are not based on information technology are no longer relevant so it has a huge impact on vocational schools that require more practicums directly.

b. The competencies taught at Vocational School are less relevant to the entrepreneurial competencies currently required by students to open new business fields independently in the digital age.

c. Less effective business center / technopark activities because the expertise program is not dominant in digital era entrepreneurship programs, so students are not motivated to entrepreneurship after graduation and Vocational School graduates are ultimately more interested in directly working in companies / industries rather than going on to college or entrepreneurship to create new jobs.

d. Lack of partnerships with entrepreneurs, so that FieldWork Practices are only implemented in companies/industries that become partners and in the end graduates are more interested in working in the company/industry where they intern. This leads to a lack of student stimulus for entrepreneurship, even though there are many motivations, potential, relationships and business opportunities that can be developed and obtained from business actors.

Solutions to overcome the obstacles of principal leadership in efforts to improve the competence of entrepreneurship students in SMK $n 1$ and $\mathbf{N}$ Metro Lampung

There are several solutions for the Principal in an effort to improve students' entrepreneurial competence including:

a. Vocational High School is required to facilitate and improve the competence of teachers in carrying out learning technology, as well as designing the curriculum in such a way that students' practicum activities can be fulfilled.

b. Vocational High School must make changes to the curriculum and learning facilities periodically in accordance with the changes and demands of the development of science and technology. Curriculum adjustments can be made by looking at the changing needs of industry 4.0 , so that students can prepare well. This readiness must be done, so that students have adequate competence.

c. Vocational High School must facilitate and manage business centers / technopark creatively and innovatively in order to inspire and motivate students to develop students' entrepreneurial potential and start their business early.

d. Vocational High School establishes partnerships with national or international business people to serve as internships, so that students can be motivated and inspired to develop their talents and interests to start a business and have a high fighting spirit to run their business early.

\section{CONCLUSION}

Research result can be concluded that the Principal has sought to improve the entrepreneurial competence of students through various areas of expertise organized, but even so the entrepreneurship competence of graduates is still low. This is evidenced by the lack of graduates who entrepreneurship independently before graduation and after graduating 1 year. While mentioned in the Accreditation Guidelines of the National Accreditation Board of Schools/Madrasah of West Java Province in 2020, that indicators of the high quality of entrepreneurship graduates can be seen from at least $10 \%$ of existing students who are 
entrepreneurship before graduation, and at least $50 \%$ of graduates have entrepreneurship after graduating one year.

\section{REFERENCES}

Fakhrunnisa, R. (2019). Strategi Kepemimpinan Kepala Sekolah Dalam Pengembangan Profesionalisme Guru Di SMK Negeri 2 Temanggung 2018/2019 (Universitas Muhammadiyah Surakarta).

Hunger, David \& Wheelen, (2012). Manajemen Strategis. Diterjemahkan oleh Julianto Agung S. Jakarta: Salemba Empat

Sriwahyuni, E., Kristiawan, M., \& Wachidi, W. (2019). Strategi Kepala Sekolah Dalam Mengimplementasikan Standar Nasional Pendidikan (SNP) Pada SMK Negeri 2 Bukittinggi. JMKSP (Jurnal Manajemen, Kepemimpinan, dan Supervisi Pendidikan), 4(1), 21-33.

Sugiyono,(2012). Metode Penelitian Pendidikan, Bandung: Alfabeta.

Suriansyah, A., \& Aslamiah. (2015). Strategi Kepemimpinan Kepala Sekolah, Guru, Orang Tua, Dan Masyarakat Dalam Membentuk Karakter Siswa. Jurnal Cakrawala Pendidikan, 34(2), 234-247

Sutisna, S., \& Widiarto, T. (2020). Pengaruh Kedisiplinan Dan Sikap Mandiri Terhadap Minat Berwirausaha Pada Siswa SMK Di Kota Bogor. 6(2), 23-28.

Syaodih, Nana (2005).. Metode Penelitian Pendidikan. Bandung:Remaja Rosdakarya.

Wahyudi. (2019). Kepemimpinan Kepala Sekolah Dalam Organisasi Pembelajar (Learning Jurnal Ilmiah Ilmu Sosial), 5(1), pp. 132-141

Widaningrum, Fadilah (2019). Analisis Relevansi Visi, Misi, Tujuan, dan Kurikulum Antara SMKN 1 Kedawung Sragen dan SMK N 1 Bawen Semarang. 17(2)

Yayat M. Herujito (2001). Dasar-Dasar Manajemen. Jakarta: P.T. Grasindo

Yin, Robert (2013). Studi Kasus Desain dan Metode. Jakarta: PT. Raja Grafindo. Persada.

Yulmawati. (2016). Strategi Kepemimpinan Kepala Sekolah Dalam Meningkatkan Mutu Pendidikan SD Negeri 03 Sungayang. Jurnal Manajemen, Kepemimpinan, dan Supervisi Pendidikan, 1(2), 109-121 